\title{
Pengembangan Sintaks Pembelajaran Fisika Berbasis Kearifan Lokal Bagi Peserta Didik SMK Negeri 1 Sulawesi Selatan
}

\author{
M.Agus Martawijaya \\ Universitas Negeri Makassar \\ martawijayamagus@gmail.com
}

\begin{abstract}
Abstrak - Telah dilakukan penelitian yang berjudul pengembangan sintaks pembelajaran fisika berbasis kearifan lokal bagi peserta didik SMK Negeri 1 Sulawesi Selatan. Penelitian ini bertujuan untuk menghasilkan sintaks pembelajaran fisika berbasis kearifan lokal yang valid, praktis, dan efektif bagi peserta didik SMK Negeri 1 Sulawesi Selatan. Penelitian ini termasuk jenis penelitian pengembangan yang dilaksanakan pada semester Ganjil tahun ajaran 2016/2017 yang bertempat di Makassar, Sulawesi Selatan. Subjek dalam penelitian ini adalah sebanyak 5 peserta didik pada uji coba terbatas, dan sebanyak 10 peserta didik pada uji coba yang lebih luas di kelas X SMK Negeri 1 Sulawesi Selatan. Hasil penelitian yang diperoleh menunjukkan bahwa secara keseluruhan sintaks pembelajaran fisika berbasis kearifan lokal dinyatakan valid berdasarkan hasil analisis validasi 2 orang ahli, praktis berdasarkan penilaian 2 orang pengamat pelaksanaan sintaks pada saat ujicoba, dan efektif berdasarkan persentase respon positif pendidik dan peserta didik, sehingga sintaks pembelajaran fisika berbasis kearifan lokal dinyatakan valid, praktis, dan efektif bagi peserta didik dan pendidik di SMK Negeri 1 Sulawesi Selatan.
\end{abstract}

Kata kunci: kearifan lokal, pembelajaran fisika, sintaks

Abstract - Has conducted a study entitled development of physics learning syntax based on local wisdom for students of SMK Negeri 1 South Sulawesi. This study aims to produce syntax of learning physics based on local wisdom, are valid, practical, and effective for students of SMK Negeri 1 South Sulawesi. This research includes development research conducted in odd semester of 2016/2017 academic year was held in Makassar, South Sulawesi. Subjects in this study were as many as five students on limited trial, and as many as 10 students in a wider trial in class X SMK Negeri 1 South Sulawesi. The results obtained showed that overall syntax of learning physics based on local wisdom declared invalid based on the analysis of validation 2 experts, practical based on ratings 2 observers implementation syntax at the time of trial, and effective based on the percentage of positive responses of teachers and students, so the syntax learning physics based on local wisdom is valid, practical, and effective for students and teachers at SMK Negeri 1 South Sulawesi.

Key words: local wisdom, physics learning, syntax

\section{PENDAHULUAN}

Perubahan Kementerian Pendidikan Nasional (Kemendiknas) menjadi Kementerian Pendidikan dan Kebudayaan (Kemendikbud) merupakan salah satu upaya Pemerintah Republik Indonesia (RI) untuk mewujudkan fungsi dan tujuan pendidikan nasional RI. Hal yang paling mendasar pada perubahan tersebut yaitu adanya transformasi budaya yang dimasukkan ke dalam pendidikan. Salah satu tujuannya adalah untuk mendayagunakan kondisi alam, sosial dan budaya yang dimiliki oleh setiap daerah di Indonesia.

Tujuan tersebut di atas mengisyaratkan bahwa aspek budaya masyarakat hendaknya menjadi pengarah yang normatif terhadap pelaksanaan pembelajaran pada satuan pendidikan (Joni, dkk., 1985: 64). Aspek budaya yang dimaksudkan tidak lain adalah kearifan lokal masyarakat setempat (local wisdom) itu sendiri. Oleh karena itu, proses pembelajaran harus menempatkan peserta didik dalam lingkungan sosial budayanya, mengembangkan kehidupan peserta didik sebagai warga negara yang tidak kehilangan kepribadian, kualitas kehidupan yang lebih baik dan nilainilai kearifan lokal, sehingga peserta didik dapat membangun kehidupan masa depan yang lebih baik lagi (Kemendikbud, 2013: 83). Nilai-nilai kearifan lokal dimaksudkan sebagai acuan bagi peserta didik dalam memperoleh pengetahuan yang baik, dan acuan bagi pendidik dalam berbagi pengetahuan yang baik pula.

Sehubungan dengan penanaman nilai-nilai kearifan lokal dalam ranah pelaksanaan pendidikan, Martawijaya (2014) telah melakukan penelitian dan pengembangan dengan judul "Model Pembelajaran Fisika Berbasis Kearifan Lokal untuk Meningkatkan Karakter dan Ketuntasan Belajar Peserta Didik di SMP Pulau Barrang Lompo". Hasil penelitian tersebut menunjukkan bahwa karakter dan ketuntasan belajar peserta didik yang awalnya memperihatinkan mengalami peningkatan menjadi lebih baik. Selain itu, peserta didik yang memiliki karakter dan ketuntasan belajar yang baik juga turut mengalami peningkatan menjadi lebih baik. Pertanyaannya, apakah pengembangan tersebut hanya semata untuk peserta didik SMP? Jawabannya, tidak. Pengembangan tersebut juga dapat digunakan di jenjang pendidikan Sekolah Dasar (SD) atau Madrasah Ibtidayyah (MI), Madrasah Tsanawiyah (MTs), Sekolah Menengah 
Atas (SMA) atau Madrasah Aliyah (MA), dan juga Sekolah Menengah Kejuruan (SMK).

Namun untuk keperluan desiminasi di jenjang tersebut di atas, harus ada modifikasi, adaptasi, atau revisi terhadap produk yang telah dikembangkan pada penelitian Martawijaya. Sehingga jika hal tersebut dikhendaki untuk digunakan pada jenjang lainnya, maka harus ada pengembangan lebih lanjut pada bagian yang mendasar dalam Model, yaitu SINTAKS. Adapun fase Sintaks yang akan dikembangkan dalam penelitian ini adalah: (1) fase 1.Minasa Baji (niat yang baik); (2) fase 2.Akkana Baji (ungkapan yang baik); (3) fase 3.Gaukang Baji (kerja yang baik); (4) fase 4.Ukiri Baji (tulisan yang baik); (5) fase 5.Sabbiri Baji (persaksian yang baik); dan (6) fase 6.Mabbarakka (berberkah). Spesifikasi yang mencirikan perbedaan sintaks ini dengan sintaks yang digunakan Martawijaya pada pengembangan Model Pembelajarannya terdapat pada fase ke-6, yaitu Mabbarakka. Mabbarakka merupakan fase terakhir pada sintaks tersebut dengan tujuan agar segala kegiatan pembelajaran yang dilakukan peserta didik dan pendidik memiliki berkah bagi diri sendiri maupun lingkungan sekitarnya.

Sehubungan dengan fase Sintaks pembelajaran tersebut di atas, maka penulis berpandangan bahwa jenjang pendidikan yang paling cocok untuk dijadikan sebagai subjek dalam pengembangan sintaks pembelajaran adalah peserta didik SMK. Karena SMK memiliki karakteristik tersendiri dalam pembelajarannya, yakni $60 \%$ praktik dan $40 \%$ teori. SMK juga merupakan sekolah yang operasional, dimana ilmu yang diperoleh tidak hanya sebatas pengetahuan, tetapi peserta didik SMK harus menjadikan ilmu tersebut berguna atau berberkah bagi diri sendiri dan sekitarnya. Seperti hasil kerja peserta didik SMK yang mampu membuat teknologi untuk mempermudah pekerjaan manusia, sehingga berberkah bagi diri sendiri maupun lingkungan sekitarnya.

Berdasarkan rasional mengenai pengembangan sintaks pembelajaran di atas, maka penulis akan melakukan penelitian dengan judul "Pengembangan Sintaks Pembelajaran Fisika Berbasis Kearifan Lokal". Adapun komponen model lainya, seperti Sistem Sosial, Prinsip Reaksi, Sistem Pendukung, dan Dampak Model tidak mengalami perubahan, karena semua komponen tersebut hampir memiliki kesamaan budaya, yakni budaya Makassar. Pertanyaan penelitian yang hendak dijawab melalui penelitian ini adalah bagaimanakah sintaks pembelajaran fisika berbasis kearifan lokal yang valid, praktis, dan efektif?

\section{METODE PENELITIAN}

Penelitian ini merupakan penelitian pengembangan. Adapun yang dijadikan subjek dalam penelitian ini adalah peserta didik kelas X SMK Negeri 1 Sulawesi Selatan, pada semester Ganjil tahun ajaran 2016/2017 di Makassar.

Dalam penelitian ini, dikembangkan sintaks pembelajaran fisika berbasis kearifan lokal. Untuk mewujudkannya digunakan prosedur atau tahapan penelitian yang digunakan adalah diadaptasi dari tahapan pengembangan sebagaimana yang dikemukakan oleh Sugiyono (2012: 298), tetapi dalam penelitian ini belum sampai pada tahap produksi massal. Adapun bagan yang menunjukkan prosedur penelitian ini adalah sebagai berikut.

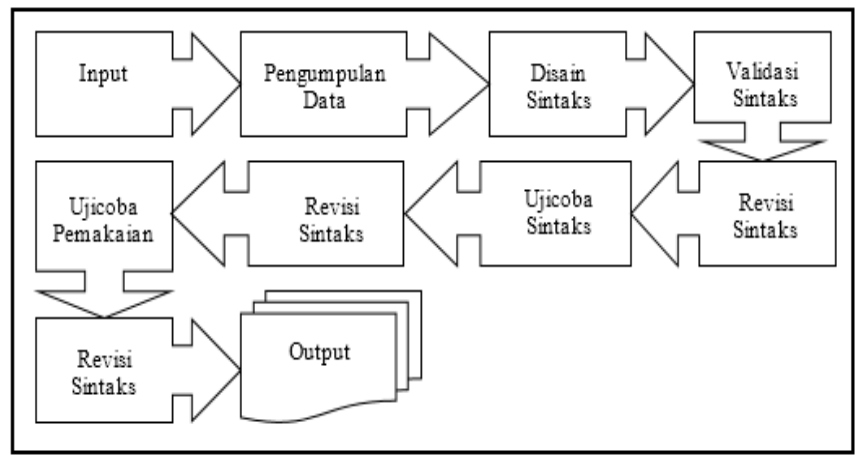

Gambar 1. Tahapan Penelitian (Sugiyono,2012)

Instrumen penelitian yang digunakan dalam penelitian ini terdiri atas: (1) instrumen kevalidan berupa format penilaian sintaks yang dinilai oleh dua orang validator ahli; (2) instrumen kepraktisan berupa penilaian keterlaksanaan sintaks pembelajaran selama uji coba dilakukan oleh dua orang pengamat; dan (3) instrumen keefektifan berupa persepsi peserta didik terhadap kegiatan dan proses pembelajaran yang telah diikuti dengan menggunakan sintaks pembelajaran fisika berbasis kearifan lokal.

Teknik analisis data yang akan digunakan dalam penelitian ini adalah menggunakan justifikasi ahli/pakar sebanyak 2 (dua) orang, dengan menggunakan teknik analisis Gregory. Sintaks pembelajaran fisika berbasis kearifan lokal dikatakan valid apabila hasil analisis data menunjukkan bahwa sintaks pembelajaran fisika berbasis kearifan lokal berada pada kategori valid dengan nilai realiabilitasnya $(R) \geq 0,75$ (Borich, 2011: 209).

Sintaks pembelajaran fisika berbasis kearifan lokal dikatakan praktis apabila hasil analisis data pengamatan 2 (dua) observer terhadap keterlaksanaan sintaks menunjukkan bahwa sintaks pembelajaran fisika berbasis kearifan lokal berada pada kategori terlaksana seluruhnya dengan nilai realiabilitasnya $(R) \geq 0,75$ (Borich, 2011: 209).

Sintaks pembelajaran fisika berbasis kearifan lokal dikatakan efektif apabila memenuhi kriteria respons peserta didik terhadap sintaks pembelajaran fisika berbasis kearifan lokal yang telah diikuti. Data tentang respons peserta didik diperoleh dari angket respons peserta didik yang selanjutnya dianalisis dengan persentase. Kegiatan yang dilakukan untuk menganalisis data respons tersebut adalah:

1. Menghitung banyaknya peserta didik yang memberi respons positif sesuai dengan aspek yang ditanyakan, kemudian menghitung persentasenya.

2. Menentukan kategori untuk respons positif peserta didik dengan cara mencocokkan hasil persentase dengan kriteria yang ditetapkan.

3. Jika hasil analisis menunjukkan bahwa respons peserta didik belum positif, maka dilakukan revisi terhadap perangkat yang dikembangkan.

Kriteria yang ditetapkan untuk mengatakan bahwa peserta didik memiliki respons positif terhadap sintaks 
pembelajaran fisika berbasis kearifan lokal adalah lebih dari $50 \%$ dari mereka memberi respons positif terhadap minimal 70\% jumlah aspek yang ditanyakan (Nurdin, 2007:155). Keefektifan sintaks pembelajaran fisika berbasis kearifan lokal dikatakan tercapai apabila kriteria respons positif peserta didik terpenuhi.

\section{HASIL DAN PEMBAHASAN}

Hasil yang diperoleh dalam penelitian ini, berkenaan dengan 3 (tiga) rumusan masalah, yakni sebagai berikut.

\section{Kevalidan sintaks pembelajaran fisika berbasis kearifan lokal}

Sintaks pembelajaran fisika berbasis kearifan lokal yang dikembangkan dalam penelitian ini terdiri atas 6 (enam) fase, yaitu: Minasa Baji, Ada Baji, Gau Baji, Uki Baji, Sabbi Baji, dan Mabbarakka. Kevalidan setiap fase tersebut adalah sebagai berikut.

1)Nilai Rata-rata total kevalidan rasional sintaks pembelajaran fisika berbasis kearifan lokal yang diperoleh yaitu $\bar{x}=4,0$. Berdasarkan kriteria kevalidan yang telah dinyatakan pada bab 4, nampak bahwa nilai tersebut berada pada kategori "sangat valid".

2)Nilai Rata-rata total kevalidan operasional sintaks pembelajaran fisika berbasis kearifan lokal yang diperoleh yaitu $\bar{x}=3,9$. Komponen operasioanl sintaks terdiri atas fase Minasa Baji, Ada Baji, Gau Baji, Uki Baji, dan Mabbarakka. Berdasarkan kriteria kevalidan yang telah dinyatakan pada bab 4, nampak bahwa nilai tersebut berada pada kategori "sangat valid".

3)Nilai Rata-rata total kevalidan interaksi pendidik dan peserta didik dalam sintaks pembelajaran fisika berbasis

kearifan lokal yang diperoleh yaitu $\bar{x}=3,9$. Berdasarkan kriteria kevalidan yang telah dinyatakan pada bab 4 , nampak bahwa nilai tersebut berada pada kategori "sangat valid".

4)Nilai Rata-rata total kevalidan sistem pendukung sintaks pembelajaran fisika berbasis kearifan lokal yang diperoleh yaitu $\bar{x}=4,0$. Berdasarkan kriteria kevalidan yang telah dinyatakan pada bab 4, nampak bahwa nilai tersebut berada pada kategori "sangat valid".

Setelah sintaks pembelajaran fisika berbasis kearifan lokal dinyatakan valid melalui proses validasi dan direvisi berdasarkan saran-saran perbaikan dari para validator, maka diperoleh "Sintaks Pembelajaran Fisika Berbasis Kearifan Lokal" yang dapat diterapkan di lapangan untuk melihat kepraktisan dan keefektifannya.

\section{Kepraktisan sintaks pembelajaran fisika berbasi kearifan lokal}

Kepraktisan sintaks pembelajaran fisika berbasis kearifan lokal diperlihatkan melalui data pengelolaan pembelajaran selama ujicoba oleh pendidik fisika (guru model). Pengelolaan pelaksanaan "Model PEKABEKAL I" difokuskan pada komponen setiap fase sintaks pembelajaran berbasis kearifan lokal dan diamati oleh 2 (dua) orang pengamat. Adapun hasil yang diperoleh adalah sebagai berikut.

a)fase-Minasa Baji. Rata-rata kemampuan pendidik mengelola fase Minasa Baji adalah 3,45. Jika dikonfirmasi dengan kriteria pengelolaan pembelajaran seperti pada bab 4, maka dapat diyakini bahwa kemampuan pendidik mengelola sintaks pembelajaran berbasis kearifan lokal termasuk kategori sangat tinggi $(3,0 \leq \mathrm{KG} \leq 4,0)$.

b)fase-Ada Baji. Rata-rata kemampuan pendidik mengelola fase Ada Baji adalah 3,42. Jika dikonfirmasi dengan kriteria pengelolaan pembelajaran seperti pada bab 4, maka dapat diyakini bahwa kemampuan pendidik mengelola sintaks pembelajaran berbasis kearifan lokal termasuk kategori sangat tinggi $(3,0 \leq \mathrm{KG} \leq 4,0)$.

c) fase-Gau Baji. Rata-rata kemampuan pendidik mengelola fase Gau Baji adalah 3,41. Jika dikonfirmasi dengan kriteria pengelolaan pembelajaran seperti pada bab 4, maka dapat diyakini bahwa kemampuan pendidik mengelola sintaks pembelajaran berbasis kearifan lokal termasuk kategori sangat tinggi $(3,0 \leq \mathrm{KG} \leq 4,0)$.

d)fase-Uki Baji. Rata-rata kemampuan pendidik mengelola fase Uki Baji adalah 3,38. Jika dikonfirmasi dengan kriteria pengelolaan pembelajaran seperti pada bab 4, maka dapat diyakini bahwa kemampuan pendidik mengelola sintaks pembelajaran berbasis kearifan lokal termasuk kategori sangat tinggi $(3,0 \leq \mathrm{KG} \leq 4,0)$.

e) fase-Sabbi Baji. Rata-rata kemampuan pendidik mengelola fase Gau Baji adalah 3,38. Jika dikonfirmasi dengan kriteria pengelolaan pembelajaran seperti pada bab 4, maka dapat diyakini bahwa kemampuan pendidik mengelola sintaks pembelajaran berbasis kearifan lokal termasuk kategori sangat tinggi $(3,0 \leq \mathrm{KG} \leq 4,0)$.

f) fase-Mabbarakka. Rata-rata kemampuan pendidik mengelola fase Mabbarakka adalah 3,41. Jika dikonfirmasi dengan kriteria pengelolaan pembelajaran seperti pada bab 4, maka dapat diyakini bahwa kemampuan pendidik mengelola sintaks pembelajaran berbasis kearifan lokal termasuk kategori sangat tinggi $(3,0 \leq \mathrm{KG} \leq 4,0)$.

g) suasana kelas. Rata-rata kemampuan pendidik mengelola sintaks pembelajaran berbasis kearifan lokal mengenai suasana kelas adalah 3,40. Jika dikonfirmasi dengan kriteria pengelolaan pembelajaran seperti pada bab 4, maka dapat diyakini bahwa kemampuan pendidik mengelola sintaks pembelajaran berbasis kearifan lokal termasuk kategori sangat tinggi $(3,0 \leq \mathrm{KG} \leq 4,0)$.

Rerata kemampuan pendidik mengelola sintaks pembelajaran fisika berbasis kearifan lokal secara keseluruhan adalah 3,40. Jika dikonfirmasi dengan kriteria pengelolaan pembelajaran seperti pada bab 4, maka dapat diyakini bahwa kemampuan pendidik mengelola sintaks pembelajaran berbasis kearifan lokal termasuk kategori tinggi $(3,0 \leq \mathrm{KG} \leq 4,0)$. Dengan kata lain, keterlaksanaan sintaks pembelajaran fisika berbasis kearifan lokal dinyatakan terlaksana seluruhnya. 


\section{Keefektivan sintaks pembelajaran fisika berbasis kearifan lokal}

Keefektifan sintaks pembelajaran fisika berbasis kearifan lokal diperlihatkan melalui data mengenai respon pendidik dan peserta didik setelah menggunakan sintaks tersebut dalam pembelajaran fisika.

Hasil analisis data respon peserta didik dan pendidik terhadap penerapan sintaks pembelajaran fisika berbasis kearifan lokal beserta perangkat pembelajarannya sebagai pendukung, yaitu: (1) hasil analisis data menunjukkan bahwa $100 \%$ peserta didik memberikan respon positif terhadap perangkat dan penerapan sintaks pembelajaran fisika berbasis kearifan loka; dan (2) hasil analisis data menunjukkan bahwa pendidik memberikan respon positif terhadap perangkat dan penerapan sintaks pembelajaran fisika berbasis kearifan lokal.

Terlepas dari segala keterbatasan penelitian ini telah diperoleh gambaran mengenai pengembangan sintaks pembelajaran fisika berbasis kearifan lokal di SMK Negeri 1 Sulawesi Selatan, yang valid, praktis dan efektif. Dalam penelitian ini, tim peneliti berharap bahwa validator, observer, pendidik, dan peserta didik menunjukkan respon yang positif terhadap pengembangan sintaks pembelajaran fisika berbasis kearifan lokal.

Hasil penelitian menunjukkan bahwa masih terdapat respon peserta didik yang menyatakan senang mengikuti pembelajaran tetapi kesulitan dalam hal melaksanakan kegiatan pembelajaran pada fase Gau Baji. Hal ini dikarenakan bahwa sebagian dari peserta didik masih ada yang belum bisa menggunakan alat ukur neraca pegas dengan baik dan benar. Selain itu, juga terdapat peserta didik yang baru melihat yang namanya neraca pegas. Walaupun demikian, secara keseluruhan peserta didik memberikan respon yang positif terhadap penerapan sintaks pembelajaran fisika berbasis kearifan lokal.

\section{KESIMPULAN}

Berkenaan dengan rumusan masalah, tujuan, dan hasil penelitian, maka kesimpulan dalam penelitian ini adalah sebagai berikut.

1. Sintaks pembelajaran fisika berbasis kearifan lokal bagi peserta didik SMK Negeri 1 Sulawesi Selatan dinyatakan valid berdasarkan hasil analisis validasi 2 orang validator dengan nilai rata-rata 3,90 atau berada pada kategori tinggi.

2. Sintaks pembelajaran fisika berbasis kearifan lokal bagi peserta didik SMK Negeri 1 Sulawesi Selatan dinyatakan praktis berdasarkan hasil analisis penilaian 2 orang observer dengan nilai rata-rata 3.40 atau berada pada kategori tinggi

3. Sintaks pembelajaran fisika berbasis kearifan lokal bagi peserta didik SMK Negeri 1 Sulawesi Selatan dinyatakan efektif berdasarkan persentase respon positif pendidik dan peserta didik dengan nilai rata-rata $100 \%$.

Saran yang dapat diuraikan dalam penelitian ini diperuntukkan bagi pendidik, sebaiknya dapat menerapkan sintaks pembelajaran fisika berbasis kearifan lokal pada materi fisika yang lainnya. Selain itu, pendidik mata pelajaran lainnya dapat juga melakukan adaptasi dari penelitian ini untuk menghasilkan pembelajaran yang praktis dan efektif.

\section{UCAPAN TERIMA KASIH}

Terima kasih yang sebesar-besarnya kami ucapkan kepada pimpinan Universitas Negeri Makassar, Ketua Lembaga Penelitian UNM, Kepala Sekolah, Pendidik, dan Peserta Didik SMK Negeri 1 Sulawesi Selatan, dan para rekan peneliti yang telah banyak berpatisipasi dan mendukung terlaksananya penelitian ini.

\section{PUSTAKA}

[1] Borich, G. D. 2011. Observation Skills for Effective Teaching $6^{\text {th }}$ Edition. Austin: Pearson.

[2] Gie, T. L. 2006. Pengantar Filsafat Teknologi. Yogyakarta: Andi.

[3] Joni, T. R., dkk. 1985. Pendekatan Kemampuan dalam Pengembangan Kurikulum Inti LPTK. P2LPTK, Jakarta: Depdikbud.

[4] Kemendikbud. 2013. Materi Pelatihan Guru Implementasi Kurikulum 2013. Jakarta: Kemendikbud.

[5] Kuranto, S. A. 2012. Konsep Pendidikan Berbasis Kearifan Lokal sebagai Dasar Pembentukan Karakter Bangsa. Makalah, Makassar: Program Pascasarjana Universitas Negeri Makassar.

[6] Martawijaya, M.Agus. 2014. Model Pembelajaran Fisika Berbasis Kearifan Lokal untuk Meningkatkan Karakter dan Ketuntasan belajar Peserta Didik SMP di Pulau Barrang Lompo. Disertasi. PPs UNM Makassar.

[7] McKenney, S., \& Voerman, I. V. 2013. "Formal Education of Curriculum and Instructional Designers". "ournal of The International Society for Design and Development in Education. Vol. 2 No. 6.

[8] Nurdin. 2007. Model Pembelajaran Matematika yang Menumbuhkan Kemampuan Metakognitif untuk Menguasai Bahan Ajar. Disertasi tidak diterbitkan. Surabaya: PPs Universitas Negeri Surabaya.

[9] Policy Brief. 2011. Pendidikan Karakter untuk Membangun Karakter Bangsa. Jakarta: Direktorat Jenderal Pendidikan Dasar.

[10] Salam, Burhanuddin, 2002, Pengantar Pedagogik (Dasar-Dasar Immu Mendidik), Jakarta: PT. Rineka Cipta.

[11] Suastra, I W. 2010. "Model Pembelajaran Sains Berbasis Budaya Lokal untuk Mengembangkan Komopetensi Dasar Sains dan Nilai Kearifan Lokal di SMP”. Jurnal Pendidikan dan Pengajaran. Jilid 43, Nomor 2, April 2010, hlm. 8-16.

[12] Subagia, I W. dan Wiratma, I G. L. 2006. "PotensiPotensi Kearifan Lokal Masyarakat Bali dalam Bidang Pendidikan”. Jurnal Pendidikan dan Pengajaran IKIP Negeri Singaraja, No, 3, Tahun XXXIX.

[13] Sugiyono. 2012. Metode Penelitian kuntitatif, kualitatif, dan $R \& D$. Bandung: CV. Alfabeta. 